\section{Occurrence of the Alga Gloeocapsa in the Air}

THe pollen and fungus spore content of the air has been investigated extensively during recent years in connexion with respiratory allergy and crop diseases. Less is known of other constituents of the air spora. The occurrence of unicellular algæ in the air or in air-borne dust has been demonstrated by several investigators.

In quantitative studies of the air spora, we have observed the regular occurrence of a blue-green alga identifiable microscopically as belonging to the Chroococcaceae, probably Gloeocapsa (Fig. 1). 'This is a minute unicellular alga forming loose colonies on moist surfaces, either inland or on the sea-shore. The origin of these air-borne Gloeocapsa colonies is at present unknown; they do not appear to be lichen soredia, because most of the colonies observed were free from fungus hyphæ. The mechanism by which they get into the air is also obscure.

Data are available from three centres at each of which air was sampled almost continuously during June 30-July 13, 1954, at a height of 2 metres above ground-level, using the Hirst ${ }^{2}$ automatic volumetric spore trap, in which the solid particles in a measured volume of air are deposited in a continuous trace on a slowly moving microscope slide. The deposit on our slides was examined microscopically at distances along the trace corresponding to two-hourly intervals. The areas scanned provided estimates of the number of particles in 12 litres of air for each 2-hr. period. The highest concentration of the alga was observed at Thorney Island, Hants, where an average of 110 colonies per cubic metre of air was recorded over the period of observation. On the roof of the Botany Department, Imperial College of Science and Technology, South Kensington, and in an arable field at Rothamsted Experimental Station, Harpenden, Herts, the average concentration was only $1 / 20$ of that at Thorney Island. Table 1 shows the frequency of occurrence of Gloeocapsa colonies in the 12-litre samples, and also the mean and maximum concentration at each centre.

Table 1. OCCURRENCE of Gloeocapsa COLONIES IN THE AIR DURING

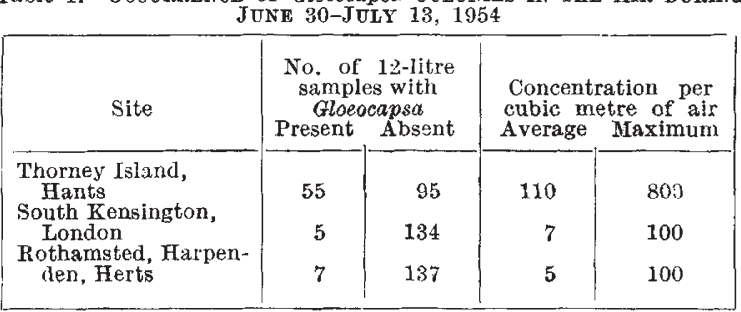

At Thorney Island the air-borne Gloeocapsa colonies averaged about eight cells each. There was a marked diurnal periodicity of occurrence : the maximum at $23.00 \mathrm{hr}$. averaged 210 colonies per cubic metre, and the minimum, between 04.00 and $13.00 \mathrm{hr}$., averaged about 30 colonies per cubic metre. Their occurrence was not obviously related to the state of the tide. At Rothamsted and South Kensington, concentrations are known to have been somewhat higher during mid-June 1954 than they were during the period described when sampling was also in progress at Thorney Island.

The concentrations recorded so far are small in comparison with those normal for pollen or fungus spores. They are nevertheless high enough at Thorney Island to indicate that air dispersal may be important

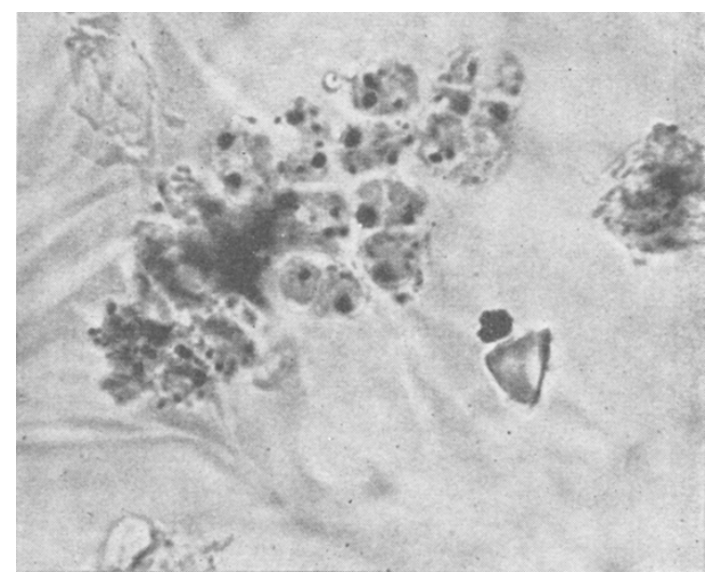

Fig. 1. Group of cells of Gloeocapsa type from air sampled at Thorney Island, $21.00 \mathrm{hr}$., July $6,1954 . \times 500$ approximately

in Gloeocapsa. With an average concentration of about 800 cells per cubic metre of air for at least three weeks, this organism warrants further study as a potential allergen, especially as the cells of Gloeocapsa are embedded in a thick sheath of mucilage.

In connexion with these observations, acknowledg ment is made to the Medical Research Council; to the Director of the Meteorological Office for the assistance given by the meteorological staff at R.A.F., Thorney Island; and to Dr. J. M. Hirst, Rothamsted Experimental Station, Harpenden.

\section{P. H. Gregory \\ Elizabeth D. Hamilton \\ T. Sreeramulu}

Department of Botany,

Imperial College of Science and Technology, London, S.W.7.

Aug. 27.

'Ehrenberg, C. G., "Passat-Staub und Blut-Regen", 192 (Berlin 1849). Salisbury, J. H., A mer. J. Med.Sci., 51, 51 (1866). Cunning ham, D. D., "Microseopic Examinations of Air", 58 (Calcutta, 1873). Yarwood, A. R., D.S.I.R. "The Investigation of Atmospheric Pollution", 16th Report, 11 (H.M.S.O., 1931). Rempe. H., Planta, 27, 93 (1937). Meier, F. C., Sci. Mon., New York 40, 5 (1935). Polunin, N., Svensk. Bot. Tidskr., 45, 320 (1951). 2 Hirst, J. M., Ann. App. Biol., 39, 257 (1952).

\section{Seasonal Changes in Three Common Constituents of the Air Spora of Southern Nigeria}

Fluctuations in the air spora have been studied in a temperate climate by Hirst ${ }^{1,2}$ and others. Less is known of the changes which occur in the tropics. The study of these changes is valuable in assisting the prediction and analysis of epidemics of plant disease due to air-borne fungi.

The observations described below were made at the Federal Department of Agricultural Research, Ibadan, Western Region, Nigeria. The station is at lat. $7^{\circ} 23^{\prime}$ N., long. $3^{\circ} 50^{\prime}$ E. at an elevation of $600 \mathrm{ft}$. above mean sea-level and lies on the edge of the lowland rain forest belt. The annual rainfall is 45-50 in. and typically there is a dry season from December to March and a rainy season from April to November, with a short break during the first half of August. Further details of the vegetation are given by $\mathrm{Keay}^{3}$ and of the climate by Brooks ${ }^{4}$. 